\title{
WALI DAN KARAMAH AMANG GAGA DI DESA UJUNG BARU, KECAMATAN BATI-BATI, KABUPATEN TANAH LAUT
}

\author{
Zakiah \& Abdul Hakim
}

Fakultas Ushuluddin dan Humaniora

Diterima tanggal 10 Oktober 2016 / Disetujui tanggal 27 Oktober 2016

\begin{abstract}
This research took up from perspective about the importance of discussing society opinion on $W$ ali's and the people are reputed as holy people or the people who has a special ability as a popular religion expression which still exists in the certain society. Paying homage by society to $W$ ali's are not only when they are still alive, but it also continue when they are died. Amang Gaga is one of them, he was respected and reputed as a Wali and he had a special ability (karamah) by people in Ujung Baru village, BatiBati, with the result that this research needs to be done. The questions of this research are (1) How does people opinion about Wali and Amang Gaga's karamah? (2) What is level of guardian status of Amang Gaga as a Wali and his karamah according to tasamwuf?. Based on the findings that Amang Gaga is a Wali because his loyalty, his consistency and his karamah. The level of his guardian status is al-Quthub atau al-Ghawts. It means that the bumans need him when they bave difficulties, when he prayed to Allah, it would be answered Allah very fast. People pray to Allah through him as a medium. However, there is any evidence to show that Amang Gaga as the leader of Wali's.
\end{abstract}

Kata kunci: wali, karamah, tasawuf

\section{Pendahuluan}

Tasawuf merupakan salah satu cabang dari ilmu keislaman yang lebih menekankan pada dimensi atau aspek spiritual. Ketika berkaitan dengan manusia, tasawuf lebih menekankan aspek rohaninya ketimbang aspek jasmaninya. Dalam kaitannya dengan kehidupan ini, maka tasawuf lebih menekankan kehidupan akhirat ketimbang kehidupan dunia yang fana. ${ }^{1}$

Hidupnya dunia tasawuf berbarengan dengan tumbuhnya agama Islam itu sendiri, maka dari itu ilmu tasawuf tidak lepas dari pengaruh ayat-ayat suci al-Qur'an, hadis, dan tasawuf tumbuh di dalam jiwa pendiri Islam yakni Nabi Muhammad sebagai manusia yang sempurna. ${ }^{2}$ Puncaknya ilmu tasawuf bertujuan menjadikan seseorang dekat dengan Tuhan sehingga merasakan kebahagiaan yang tidak bisa diceritakan dengan kata-kata dan dilukiskan dengan apapun juga. ${ }^{3}$

Dalam dunia tasawuf ada bentuk kesempurnaan manusia yakni dengan anugerah akal dan hati sebagai tolak ukurnya selain agama itu sendiri. Hati sebagai bagian diri manusia memiliki fungsi untuk bertemu dengan Allah dan memposisikan diri sedekat mungkin dengan Allah. Dimana dengan kedekatan inilah yang mengantarkan manusia menjadi seorang hamba terpilih dan menjadi wali Allah. ${ }^{4}$

Dalam kehidupan ini, para wali memiliki kehormatan dan kedudukan yang tinggi di tengah-tengah masyarakat. Penghormatan masyarakat terhadap para wali tidak hanya pada waktu mereka hidup, tetapi juga

${ }^{1}$ Ahmad Bangun Nasution dan Rayani Hanum Siregar, Akblak Tasawnf: Mengenal, Pemahaman, dan Pengaplikasiannya disertai Biografi dan Tokoh-tokob Sufi (Jakarta: Rajawali Pers, 2013), 12.

${ }^{2}$ Moh. Saifulloh Al-Aziz Senali, Tashamwuf dan Jalan Hidup Para Wali (Gersik: Putra Pelajar, 2000), 15.

${ }^{3}$ A. Mustafa, Filsafat Islam (Bandung: Pustaka Setia, 1997), 241.

${ }^{4}$ Harapandi Dahri, Wali Dan Keramat Dalam Islam (Jakarta: Balai Penerbitan dan Pengembangan Agama, 2007 ), 127. 
setelah mereka wafat. Walaupun mereka telah tiada, namun kisah-kisah perjalanan hidup mereka masih tetap hidup di tengah-tengah masyarakat, diceritakan kembali berulang-ulang, ditulis dalam sejumlah buku, diceritakan dalam ceramah keagamaan, bahkan sampai dipublikasikan menjadi sejumlah film yang mengisahkan kejadian yang menakjubkan serta kegiatan mereka dalam menyebarkan agama. ${ }^{5}$ Pandangan masyarakat terhadap kewalian dan karamah ini masih terpelihara dengan baik sampai saat ini meskipun terdesak oleh cara berpikir rasional akibat modernitas yang memasuki hingga ke pelosok desa.

Begitu banyak kisah para wali yang di dalamnya mengisahkan kehidupan para wali yang luar biasa dan hampir seluruhnya memuat kisah-kisah ajaib yang kadang dianggap aneh dan tidak bisa diterima secara rasional oleh kaum akademik yang modern dan rasional. ${ }^{6}$ Hingga kini kepercayaan pada para wali dan orangorang yang dianggap suci atau memiliki keistimewaan merupakan ekspresi keagamaan populer yang masih tetap hidup ditengah-tengah masyarakat. ${ }^{7}$ Tidak terkecuali pada masyarakat Desa Ujung Baru Kecamatan Bati-bati Kabupaten Tanah Laut.

Di mata masyarakat Desa Ujung Baru, ada seorang laki-laki dari keluarga yang berkecukupan. Dia hidup pada 1930 M / 1349 H - 1970 M / 1390 H. Beliau dianggap sebagai sosok yang berbeda (melalain) namun rajin beribadah dan sederhana. Abdul Gaus atau yang akrab disapa Amang $^{8}$ Gaga $^{9}$ namanya. Semasa hidupnya dianggap sebagai orang yang berbeda dan dihormati oleh sebagian masyarakat di Desa Ujung Baru dan sekitarnya. ${ }^{10}$

Amang Gaga dikenal sebagai orang yang istiqamah dalam beribadah. Dia sangat rajin pergi ke Masjid untuk mengerjakan sholat. Amang Gaga juga sering bangun tengah malam untuk shalat dan berdzikir, bahkan sering larut dengan dzikirnya. Selain itu, beliau juga senang ikut tadarus al-Qur'an. ${ }^{11}$ Sesudah Amang Gaga wafat, banyak masyarakat yang berziarah dan mengambil berkah dan berdoa kepada Allah di makam Amang Gaga yang dianggap masyarakat sebagai wali Allah. Karena banyaknya doa dan hajat masyarakat yang terkabulkan maka hal itu menambah keyakinan masyarakat bahwa Amang Gaga adalah wali Allah (orang yang benar-benar dekat dengan Allah), sehingga makam beliau termasuk makam yang dikeramatkan.

\section{Mengenal Wali Amang Gaga}

Amang Gaga memiliki nama asli Abdul Gaus bin H. Abdul Mannan bin Abdurrahman bin Adnan. Dia merupakan anak bungsu dari pasangan $\mathrm{H}$. Abdul Mannan dan $\mathrm{Hj}$. Khadijah yang lahir di Desa Ujung Kec.

${ }^{5}$ Asep Usman Ismail, Apakah Wali itu Ada (Jakarta: PT. Raja Grafindo Persada, 2015), 4.

${ }^{6}$ Asep Usman Ismail, Apakah Wali itu $A d a, 4$.

${ }^{7}$ Asep Usman Ismail, Apakah Wali itu Ada, 13.

${ }^{8}$ Amang merupakan panggilan dalam bahasa masyarakat Desa Ujung Baru kepada seorang laki-laki yang dalam bahasa Indonesia memiliki arti sepadan dengan Paman. Lihat Abdul Djebar Hapip, Kamus Bahasa Banjar - Indonesia (Kalimantan Banjarmasin: PT Grafika Wangi, 1986 ), 3.

${ }^{9}$ Penyebutan Gaga itu karena beliau mempunyai kekurangan dalam bertutur (dalam bahasa setempat disebut aga).

${ }^{10}$ Noor Iriansyah, Wawancara Pribadi, 16 Juni 2015.

${ }^{11}$ Auria, Petani, Wawancara Pribadi, Ujung, 13 Juni 2014. 
Bati-bati Kab. Tanah Laut, dulu nama desa itu adalah desa Ujung yang tepatnya di daerah Ulinanyar, namun sekarang daerah itu menjadi bagian dari Desa Ujung Baru setelah diadakan pemekaran tahun $1980 .{ }^{12}$

H. Abdul Mannan dan Hj. Khadijah merupakan pasangan suami istri yang hidup dengan rukun, dan damai. Mereka tergolong keluarga ekonomi menengah ke atas. Sebagaimana kebanyakan penduduk desa saat itu yang memiliki profesi sebagai pertani sawah, berkebun, sebagian lagi mencari tanaman purun, dan membuat kerajinan anyaman dari purun seperti tikar dan keranjang (bakul). ${ }^{13}$

Begitu pula H. Abdul Mannan yang merupakan seorang tokoh desa (yang dituakan) dan dihormati oleh penduduk desa saat itu. Dia merupakan salah seorang pelopor dari pendirian Langgar Ulinanyar yang dibangun dekat rumahnya. Di samping bertani dan berkebun, H. Abdul Mannan juga banyak memiliki tanah perkebunan (dukub) dan peternakan kerbau (Hadangan) yang cukup berhasil membuat perekonomian keluarganya semakin meningkat. Dari penghasilannya tersebut, dibantu oleh swadaya masyarakat dibangunlah sebuah langgar di daerah Ulinanyar, tepat di samping kediaman H. Abdul Mannan. ${ }^{14}$

Dari pernikahan $\mathrm{H}$. Abdul Mannan dan $\mathrm{Hj}$. Khadijah lahirlah tujuh orang anak yang terdiri dari tiga laki-laki dan empat orang perempuan, yaitu: pertama, H. Abd. Samad atau julak Dusamad yang kemudian menikah dengan Tuan Niah dan melahirkan seorang anak bernama Aransyah atau julak Karan (Kepala Desa Ujung tahun 1960 - 1966). Kedua, H. Makmur yang memiliki istri bernama Kasrah, dari perkawinannya dengan Kasrah ini ia memiki anak tiga orang anak yaitu Sayuti, Manuarah, dan Rusni. Ketiga, Alub Basar yang memiliki suami bernama Uspa dan memiliki anak bernama Madat, Hj. Kamsiah, Saujah, Suanang Puanis, Busu Acut. ${ }^{15}$ Adapun anak keempat yakni Hj. Indra. Ia yang menikah dengan laki-laki bernama Barham (Kepala Desa Ujung tahun 1956 - 1959). Ia memiliki 3 orang putra yang bernama Dalil, Hamdan (Kepala Desa Ujung tahun 1995 2004), dan Marsuni. Kelima, Kacil Banun, ia memiliki suami bernama Abdal dan mempunyai anak bernama Tarbiyah, Mukmin, Uriansyah. Keenam, Hj. Kacil Kapsah, ia pernah menikah namun tidak sempat menjalin rumahtangga yang langgeng dan tidak memiliki keturunan. Ketujuh, Abdul Gaus atau Amang Gaga. ${ }^{16}$

Amang Gaga yang merupakan anak bungsu ini dilahirkan di Desa Ujung sekitar tahun 1930 M/1349 H. Tidak ada kepastian tanggal dilahirkannya, karena ketika itu kesadaran masyarakat tentang pencatatan kelahiran masih sangat minim. Sepanjang hidupnya ia tidak pernah menikah sehingga tidak memiliki keturunan. ${ }^{17}$

Menurut beberapa sumber, menjelang wafat ia sempat menderita sakit, namun tidak ada yang tahu sakit apa yang dideritanya, tetapi dari gerak tubuhnya ia merasakan sakit di bagian dada. Karena ketika itu tenaga medis masih sangat minim dan tempat berobat juga sangat jauh, maka dia hanya dirawat di rumah

\footnotetext{
12Saiyah, Wawancara Pribadi, Ujung Lama, 11 Maret 2016.

${ }^{13}$ Saiyah, Wawancara Pribadi, Ujung Lama, 11 Maret 2016.

14Jamani, Wawancara Pribadi, Ujung Baru, 04 April 2016.

${ }^{15}$ Saiyah, Wawancara Pribadi, Ujung Lama, 11 Maret 2016.

${ }^{16}$ Saiyah, Wawancara Pribadi, Ujung Lama, 11 Maret 2016.

${ }^{17}$ Noor Iriansyah, Wawancara Pribadi, Ujung Lama, 16 Juni 2015.
} 
dengan pengobatan tradisional seadanya. Akibat sakitnya tersebut, berat badannya menurun, dan pada awal bulan Syawal tahun 1970 M / 1390 H ia menutup mata d di usia 40 tahun. ${ }^{18}$

Menurut cerita dari mereka yang hidup ketika itu. Ketika Amang Gaga meninggal, hujan turun selama tujuh hari tujuh malam, sehingga Kacil Kapsah (saudari Amang Gaga) memberi atap (hatap kajang) pada kubur Amang Gaga, dan pada malam ketiga naik ke langit berupa cahaya yang sangat terang. Setelah hujan reda maka masyarakat ramai berkunjung dan berziarah. Kemudian kubur Amang Gaga dibuatkan kubah oleh para peziarah sampai seperti sekarang. ${ }^{19}$

Sejak kecil Amang Gaga memiliki keterbatasan dalam berbicara. Ia bisa berbicara namun kurang jelas pengucapannya bahkan condong tidak bisa dipaham. Orang setempat menyebutnya "aga" yang kemudian menjadi Gaga. Hanya orang-orang terdekat saja yang paham apa yang diucapkannya. Kekurangan inilah yang membuatnya tidak ikut mengenyam pendidikan formal disamping memang jarak sekolah yang sangat jauh dari rumah. Walaupun demikian, Amang Gaga tetap mendapat pendidikan dari keluarga terutama dari ayahnya yang merupakan seorang tokoh kampung. ${ }^{20}$

Berbeda dari anak-anak kecil pada umumnya yang suka bermain, dari kecil dia lebih suka ikut ayahnya terutama saat beribadah dibandingkan bermain. ${ }^{21}$ Disamping itu dia juga senang membantu menjaga kebun (dukub) ketika musim buah-buahan. Amang Gaga suka dengan kesenian hadrah atau senoman, sehingga ia menjadi anggota senoman (bertugas mearak payung) yang biasa menghibur ketika acara hajatan besar seperti haji dan pernikahan. ${ }^{22}$

\section{Kewalian Amang Gaga}

Sebagian besar masyarakat (responden) mempercayai bahwa Amang Gaga adalah seorang wali Allah. Bagi mereka seorang wali itu adalah orang yang dekat dengan Allah dan dikehendaki dekat dengan-Nya, dan karena kedekatannya itulah yang membuat mereka memiliki berbagai keanehan yang ada pada diri mereka, yang biasa di anggap sebagai karamah. ${ }^{23}$

Masyarakat menganggap beliau sebagai seorang wali karena begitu banyak pengunjung yang datang baik ketika masih hidup maupun sesudah wafat. makamnya setiap hari selalu dikunjungi peziarah dari berbagai kalangan mulai dari masyarakat biasa, pedagang, buruh, pengusaha, dan para ulama. Namun yang benar-benar yakin terhadap kewalian beliau adalah para pengunjung dan masyarakat yang pernah bertemu dan mendengar cerita semasa hidupnya.

Bagi semua masyarakat (responden) Amang Gaga dikenal sebagai sosok yang baik. Amang Gaga tidak pernah mengganggu dan menyakiti orang di sekelilingnya. Meskipun terkadang ada orang yang

\footnotetext{
${ }^{18}$ Noor Iriansyah, Wawancara Pribadi, Ujung Lama, 16 Juni 2015.

${ }^{19}$ Masteka, Wawancara Pribadi, Ujung Lama, 25 April 2016.

${ }^{20}$ Saiyah, Wawancara Pribadi, Ujung Lama, 11 Maret 2016.

${ }^{21}$ Saiyah, Wawancara Pribadi, Ujung lama, 11 Maret 2016.

${ }^{22}$ Hasan, Wawancara Pribadi, Ujung, lama, 15 April 2016.

${ }^{23}$ Lahmudin, Wawancara Pribadi, Ujung Lama, 07 April 2015.
} 
mengganggunya, Amang Gaga tidak membalas. Selain itu, Amang Gaga juga dikenal sebagai orang yang taat beribadah, sholat lima waktu, sholat jum'at, mengaji dan berzikir. ${ }^{24}$ Amang Gaga dikenal sebagai orang yang istiqamah dalam beribadah. Bahkan dia sangat rajin pergi ke masjid untuk mengerjakan sholat. Amang Gaga juga sering bangun tengah malam untuk shalat dan berzikir, bahkan sering larut dengan zikirnya. Selain itu, beliau juga senang ikut tadarus al-Qur'an. ${ }^{25}$

Amang Gaga tidak pernah ketinggalan sholat jum'at, kecuali sedang sakit. Namun uniknya beliau pasti menuju tempat yang sama apabila sholat di dalam masjid yaitu di depan sebuah tiang bangunan Masjid. Apabila tempat tersebut ada yang menempati, maka beliau akan berdiri di samping orang tersebut dan menunggu sampai orang tersebut selesai sholat, kemudian mengisyaratkan agar orang tersebut menyingkir karena beliau ingin menempati tempat tersebut. ${ }^{26}$ Dengan demikian beliau selalu sholat di tempat yang sama, tepat di dekat sebuah tiang bangunan masjid. Setelah sholat jum'at biasanya Amang Gaga ke daerah jembatan 1 Bati-bati, ${ }^{27}$ yakni sekitar $2 \mathrm{~km}$ dari rumahnya dengan berjalan kaki untuk mengunjungi sanak-kerabatnya yang ada di sana. Sehingga terkadang Amang Gaga pulang kerumah ketika sudah malam hari. ${ }^{28}$

Selain itu, berbeda dari masyarakat pada umumnya yang lebih suka dan nyaman tidur dengan posisi berbaring. Amang Gaga lebih suka duduk dari pada berbaring ketika tidur, yakni di atas sebuah kursi yang terletak di teras depan rumahnya. Walaupun selalu disuruh tidur berbaring di dalam rumah, ia selalu memilih tidur dengan posisi duduk. ${ }^{29}$ Kebiasaannya yang lain yaitu ia selalu makan dengan bersih. Ketika makan dia tidak pernah menyisakan nasi sedikitpun di dalam piringnya apalagi berhamburan dilantai. Piringnya selalu bersih dari sisa makanan. Bahkan tangannya selalu dijilatnya untuk menghabiskan sisa makanan yang masih menempel. ${ }^{30}$ Selain itu, kebiasaan Amang Gaga ketika mandi selalu di tempat yang sama yaitu di salah satu anak sungai tepi hutan, hal ini karena dia tidak mau ada orang lain yang melihatnya sedang mandi. Walaupun dia mengetahui di sana terkenal banyak binatang buas seperti babi hutan dan ular. ${ }^{31}$

Sesudah Amang Gaga wafat, banyak masyarakat yang berziarah dan mengambil berkah dan berdoa kepada Allah di makam Amang Gaga yang dianggap masyarakat sebagai wali Allah. Karena banyaknya doa dan hajat masyarakat yang terkabulkan maka hal itu menambah keyakinan masyarakat bahwa Amang Gaga adalah wali Allah (benar-benar dekat dengan Allah), sehingga makam beliau termasuk makam yang dikeramatkan. ${ }^{32}$

\footnotetext{
${ }^{24}$ Noor Iriansyah, Wawancara Pribadi, Ujung Lama, 16 Juni 2015.

${ }^{25}$ Auria, Petani, Wawancara Pribadi, Ujung Lama, 13 Juni 2014.

${ }^{26}$ Auria, Petani, Wawancara Pribadi, Ujung Lama, 13 Juni 2014.

${ }^{27}$ Sekarang sudah menjadi bagian dari desa Banua Anyar.

${ }^{28}$ Hamdan, Wawancara Pribadi, Ujung Lama, 06 Mei 2016.

${ }^{29}$ Hamdan, Wawancara Pribadi, Ujung Lama, 06 Mei 2016.

${ }^{30}$ Noor Iriansyah, Wawancara Pribadi, Ujung Lama, 16 Juni 2015.

${ }^{31}$ Noor Iriansyah, Wawancara Pribadi, Ujung Lama, 16 Juni 2015.

${ }^{32}$ Hamdan, Wawancara Pribadi, Ujung Lama, 06 Mei 2016.
} 
Seorang wali tentunya haruslah menjalankan syari'at dari Tuhannya, bukan justru melanggar syariatNya. Adapun Amang Gaga menjalankan ibadah, dalam kesehariannya ia selalu menutup aurat. Hal ini terlihat dari pakaiannya, dia memakai baju lengan panjang, memakai tapib (sarung), dan peci. ${ }^{33}$

\section{Karamah Amang Gaga}

Amang Gaga memiliki berbagai keanehan atau khawariq al-'adah yang dipercaya masyarakat sebagai karamah. Keanehan atau khawariq al-'adah itulah yang membuat mereka bertambah yakin akan kewalian Amang Gaga. Adapun karamah-karamah Amang Gaga yang didapat dari penuturan masyarakat, di antaranya:

1. Kampung menjadi aman ketika Amang Gaga tidur di luar rumahnya, dan menjadi tidak aman atau ramai terjadi pencurian ketika ia tidur di rumah.

Menurut beberapa responden yang semasa dengan Amang Gaga, salah satu keistimewaan Amang Gaga ialah Amang Gaga membuat kampung menjadi aman dan tertolak dari bala. Kebiasaan Amang Gaga semasa hidupnya tidak suka tidur berbaring. Ia lebih sering tidur di teras rumah sambil duduk di sebuah kursi. Kebiasaan tidur sambil duduk ini selalu dilakukannya kecuali sedang sakit yang membuat beliau tidak kuasa duduk.

Sepanjang waktu ketika beliau tidur di luar rumah tersebut, keadaan kampung menjadi tenang dan damai. Kampung menjadi aman dari pencurian, dan perampokan. Sebaliknya ketika Amang Gaga tidur di dalam rumah, maka ketika itu kampung menjadi tidak aman dan ramai terjadi pencurian. ${ }^{34}$

2. Membuat orang yang segar bugar menjadi laif (lemah tidak berdaya).

Beberapa responden menceritakan bahwa Amang Gaga bisa membuat orang yang segar-bugar menjadi laif (lemah tidak berdaya). Salah satu responden ${ }^{35}$ yang melihat langsung kejadian itu menceritakan. Ketika sholat di masjid, Amang Gaga selalu ingin duduk ditempat yang sama yakni dekat di sebuah tiang. Beliau tidak mau tidak mau berpindah tempat setiap melaksanakan sholat di masjid. Bahkan ketika ada orang yang lebih dulu memakai tempat tersebut Amang Gaga selalu meminta untuk memberikan tempat tersebut kepadanya. Pernah suatu ketika ada seseorang yang tidak mau pindah saat diminta memberikan tempat itu kepada Amang Gaga untuk ditempati. Akibatnya tiba-tiba orang tersebut laif (lemah tidak bertenaga), sehingga Amang Gaga bisa kembali menempati tempat beliau tersebut setelah orang yang pingsan itu dibawa ke sudut masjid oleh jama'ah lainnya. ${ }^{36}$

3. Mobil yang semula dalam kondisi baik, menjadi tidak bisa berjalan, mogok, ataupun mengalami ban pecah.

${ }^{33}$ Hamdan, Wawancara Pribadi, Ujung Lama, 06 Mei 2016.

${ }^{34}$ Saiyah, Wawancara Pribadi, Ujung Lama, 11 Maret 2016.

${ }^{35}$ Marsadul Ganawi, ia mengaku secara langsung melihat kejadian itu. Lihat hasil Wawancara Pribadi, Ujung Lama, 23 November 2015.

${ }^{36}$ Marsadul Ganawi, Wawancara Pribadi, Ujung Lama, 23 November 2015. 
Amang Gaga terkadang melambaikan tangan ketika mobil lewat, mengisyaratkan agar mobil itu berhenti atau Amang Gaga ingin meminta uang kepada supir mobil. Apabila mobil tersebut tidak mau berhenti, maka mobil itu akan mogok, tidak bisa berjalan atau ban mobil itu menjadi kempes.

Walau tidak kepada semua mobil Amang Gaga melambaikan tangan, hanya mobil tertentu saja. Tetapi akibat seringnya mobil mogok karena tidak mau berhenti ketika Amang Gaga melambaikan tangannya (mengisyaratkan untuk berhenti), maka setiap kali ada mobil yang lewat, meskipun Amang Gaga tidak melambaikan tangan, para supir yang sudah kenal dengan Amang Gaga akan dengan sendirinya menghentikan mobilnya untuk sekedar berjabat tangan, mempersilahkan Amang Gaga lewat, atau sering pula memberi uang seadanya. ${ }^{37}$ Bahkan ada yang sengaja membukakan dompetnya dan mempersilahkan Amang Gaga memilih uang dan mengambil sendiri uang yang ada di dalam dompet tersebut. Namun Amang Gaga tidak pernah, mengambil dalam jumlah yang banyak, bahkan lebih sedikit dari yang sudah di rencanakan oleh si pemberi. ${ }^{38}$

4. Minum air dengan garam, menjadi pertanda akan melonjaknya harga gula dipasaran.

Setiap kali harga gula akan naik dan langka di parasan, maka Amang Gaga selalu minum air tidak pakai gula tapi pakai garam. Sehingga perilaku beliau tersebut dijadikan sebuah tanda atau peringatan. ${ }^{39}$

5. Amang Gaga bisa membuat orang kena kualat (mangatulabi).

Amang Gaga suka jalan-jalan, kadang dia mampir di warung-warung tertentu yang dikehendakinya. Ketika berhenti di warung tersebut, dia minta benang atau jarum yang kemudian disimpan di dalam sempolan sarung Amang Gaga, dan terkadang minta rokok. Tetapi Amang Gaga tidak pernah memaksa saat meminta dan selalu menerima walau cuma diberi sedikit. Apabila tidak diberi dia tidak marah dan akan segera pergi. ${ }^{40}$

Pernah suatu ketika tangannya dipukul oleh seorang pedagang yang kesal karena beliau mintaminta di warungnya. Anehnya bukan tangan Amang Gaga yang sakit, ternyata sebaliknya. Seakan kena kualat, tangan pedagang itu tidak kunjung sembuh walau sudah berobat, sampai akhirnya baru sembuh seperti sediakala setelah pedagang tersebut meminta maaf kepada Amang Gaga. ${ }^{41}$ Bahkan ada pula yang bangkrut secara perlahan dan menjadi sakit-sakitan sampai akhirnya meninggal dunia. ${ }^{42}$

6. Membuat pertanda akan adanya penerangan

Setelah sholat Jum'at Masjid Baitul Muhsinin Desa Ujung, biasanya Amang Gaga selalu berjalan ke daerah jembatan 1 yang sekarang terkenal dengan desa Banuanyar, setiap rumah sanak kerabatnya selalu ia kunjungi. Hingga sore hari setelah sholat Asar baru dia kembali kerumahnya. ${ }^{43}$

\footnotetext{
37 Saiyah, Wawancara Pribadi, Ujung Lama, 11 Maret 2016.

${ }^{38}$ Hamdan, Wawancara Pribadi, Ujung Lama, 06 Mei 2016.

${ }^{39}$ Masteka, Wawancara Pribadi, Ujung Lama, 25 April 2016.

${ }^{40}$ Saiyah, Wawancara Pribadi, Ujung Lama, 11 Maret 2016.

${ }^{41}$ Rahimah, Guru, Wawancara Pribadi, Banjarmasin, 02 Oktober 2014.

${ }^{42}$ Hamdan, Wawancara Pribadi, Ujung Lama, 06 Mei 2016.

43Saiyah, Wawancara Pribadi, Ujung Lama, 11 Maret 2016.
} 
Ketika di perjalan menuju rumah dia sering masuk ke hutan (terkenal sebagai padang hantu dan babi hutan) untuk mengambil pohon kayu, namun anehnya ia tidak pernah memakai alat untuk alat seperti parang atau alat pemotong lainnya. Dia hanya menggunakan tangan kosong, yakni dengan cara mencabutnya sampai keakar. ${ }^{44}$ Pohon kayu itu kurang lebih sebesar pergelangan balita. Padahal menurut manusia umumnya tidak sanggup kalau mencabut beberapa pohon sampai akar walau hanya sebesar pergelangan balita. Pohon kayu itu dikumpulkannya (sekitar seragapan orang dewasa), kemudian dibawanya pulang ke rumah. ${ }^{45}$

Sesampainya di rumah kayu-kayu itu disusun di bawah rumah (rumah saat itu masih berupa rumah asli adat banjar/rumah bubungan tinggi). Kayu-kayu itu kemudian dibersihkannya dari daun-daun dan ranting dan batangnya dikikis hingga mulus dan bersih. Di samping itu dia juga mengumpulakan kunangkunang yang kemudian di kumpulkan dalam beberapa toples. ${ }^{46}$

Menurut responden, perbuatan Amang Gaga ini suatu berisi beberapa isyarat tentang masa depan di antaranya: hutan tempat Amang Gaga mencari mencabut pohon kayu yang ketika itu terkenal seram karena berhantu dan banyak binatang buas ternyata sekarang menjadi pemukiman dan tempat yang sangat ramai, adapun mengenai batang kayu dan kunang-kunang diibaratkan sebagai sumber penerangan yang dulu tidak ada listrik sekarang sudah ada ada listrik. Pohon kayu yang dicabut itu Amang Gaga ibaratkan sebagai tiang listrik dan kunang-kunang dalam toples itu dianggap sebagai lampunya. ${ }^{47}$

7. Mandi kebal untuk para tentara yang ingin berperang.

Tentara-tentara sering minta mandikan dan minta doakan kepada Amang Gaga ketika hendak pergi berperang agar kebal terhadap senjata dan menang dalam pertempuran. Ketika tentara itu kembali mereka membawakan hadiah dan uang. Tetapi Amang Gaga sama sekali tidak menggunakannya.

8. Memberitahu akan terjadinya peristiwa na'as.

Bila batu putih saparanakan (mulai dari ukuran kecil sampai besar di kumpulkan) dan dibujanakan (dilempar ke langit kemudian dibiarkan jatuh kebumi seperti air hujan), maka itu sebuah pertanda akan ada orang yang mati mendadak, disambar petir, ataupun mati lamas (tenggelam). ${ }^{48}$

9. Mengabarkan akan tibanya musim kemarau

Ketika Amang Gaga berjalan-jalan keliling kampung dengan membawa gayung dan ternyata itu suatu pertanda akan terjadi musim kemarau panjang yang mengakibatkan sulitnya mencari air. ${ }^{49}$

10. Pertanda turun hujan

\footnotetext{
${ }^{44}$ Saiyah, Wawancara Pribadi, Ujung Lama, 11 Maret 2016.

${ }^{45}$ Saiyah, Wawancara Pribadi, Ujung Lama, 11 Maret 2016.

${ }^{46}$ Saiyah, Wawancara Pribadi, Ujung Lama, 11 Maret 2016.

${ }^{47}$ Saiyah, Wawancara Pribadi, Ujung Lama, 11 Maret 2016.

${ }^{48}$ Auria, Petani, Wawancara Pribadi, Ujung Lama, 13 Juni 2014.

${ }^{49}$ Auria, Petani, Wawancara Pribadi, Ujung Lama, 13 Juni 2014.
} 
Pernah juga suatu hari Amang Gaga terkencing (tekamih) di masjid pada siang hari yang cuacanya cukup panas di hari jum'at. Ternyata setelah kejadian itu hujan turun dengan deras padahal hari itu tidak ada tanda-tanda akan turunnya hujan dan waktu itu masih berlangsung musim kemarau. ${ }^{50}$

11. Pohon pisang yang dijadikan bantal untuk memandikan jenazah Amang Gaga bertunas. ${ }^{51}$

Ketika meninggal dunia yakni ketika jenazah Amang Gaga dimandikan, potongan gadang pisang yang dipakai sebagai alas penyangga jenazah Amang Gaga tumbuh dan bertunas, padahal sebelumnya tidak ada tunas sama sekali. Ini disaksikan sendiri oleh beberapa informan.

12. Ada cahaya yang sangat terang keluar dari dalam kubur Amang Gaga kemudian naik ke langit. ${ }^{52}$

Pada malam ketiga setelah wafatnya, dari kubur Amang Gaga keluar cahaya yang sangat terang dan kemudian cahaya itu naik ke langit. Cahaya tersebut disaksikan secara langsung oleh salah seorang responden yang kebetulan rumahnya berdekatan dengan makam Amang Gaga. Sejak kejadian itulah makam Amang Gaga mulai banyak diziarahi.

13. Ban kendaraan tidak kempes atau pecah ketika mengangkut beban yang berlebihan dan melalui jalan yang terjal.

Biasanya apabila pembalokan (tukang kayu) membawa kayu balok seberat setengah kubik maka ban kendaraannya pecah, karena medan yang dilalui sangat terjal, namun dengan bertawassul kepada Amang Gaga maka selamat sampai tujuan dan bannya tidak pecah, tetapi ini berlaku hanya pada saat terdesak. Hal ini berbeda ketika sipengendara sengaja dengan yakinnya menambah beban muatan dengan landasan sudah bertawassul kepada Amang Gaga. Apabila niatnya dengan sengaja seperti demikian, maka keajaiban itu tidak akan terjadi. ${ }^{53}$

14. Peziarah ditelpon oleh orang tanpa ada nama dan nomer hp.

Pernah salah seorang peziarah berencana dan berjanji ingin berziarah ke makam Amang Gaga tetapi ternyata terlewati, sehingga orang tersebut bermaksud untuk membatalkan janji itu. Ternyata ada yang penelpon misterius tanpa nomer dan bertanya mengapa tidak jadi mampir berziarah ke makam Amang Gaga, tetapi anehnya telpon itu tidak ada nomer penelponnya. ${ }^{54}$

\section{Amang Gaga dalam Kacamata Sufistik: Suatu Analisis}

Sebagian besar masyarakat (hampir semua responden) mengatakan bahwa Amang Gaga adalah seorang wali Allah. Kebanyakan dari mereka menganggap Amang Gaga sebagai seorang awliyầ Allah yang memiliki kedekatan dengan Allah, sehingga kepadanya Allah berikan beberapa kelebihan atau berbagai keanehan lainnya sebagai bukti status yang istimewa, yakni karamah.

\footnotetext{
${ }^{50}$ Ganawi, Wawancara Pribadi, Ujung Lama, 23 November 2015.

${ }^{51}$ Masuni, Wawancara Pribadi, Ujung Lama, 15 April 2016

52Jamani, Wawancara Pribadi, Ujung Baru, 04 April 2016.

${ }^{53}$ Rahmad, Wawancara Pribadi, Ujung Lama, 13 Juni 2014.

${ }^{54}$ Herawati Diah, Wawancara Pribadi, Ujung Lama, 16 Juni 2015.
} 
Pendapat masyarakat tersebut tidak jauh berbeda dengan pengertian wali pada umumnya, karena sesungguhnya wali itu berarti dekat dan tentunya orang yang bertakwa kepada Allah, sehingga Allah pun memberikan kelebihan kewalian kepadanya. Para wali adalah orang yang dipelihara oleh Allah, sehingga mereka dapat menjauhkan diri dari perbuatan dosa, baik dosa besar maupun kecil sehingga kalbu mereka bercahaya dan tenggelam kepada zat Tuhannya. ${ }^{55}$ Dalam keadaan inilah para wali kemudian tidak merasa takut dan cemas. Sebagaimana tercantum dalam Q.S. Yunus/10: 62-63:

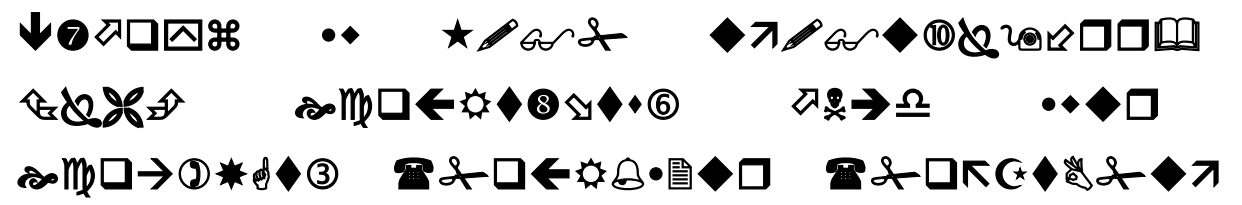

- mवर(2)

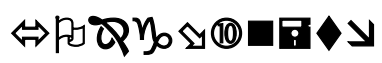

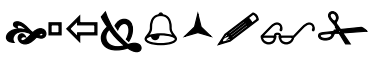

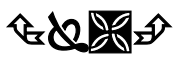

"Ingatlah, Sesungguhnya wali-wali Allah itu, tidak ada kekhawatiran terhadap mereka dan tidak pula mereka bersedih hati, yaitu orang-orang yang beriman dan mereka selalu bertakwa"

Pendapat tersebut boleh jadi benar atas izin Allah, karena tidak ada yang tidak mungkin di hadapan Tuhan. Namun pandangan seperti itulah yang membawa kepada pemahaman bahwa Amang Gaga adalah orang yang ma'shum (terjaga dari segala perbuatan dosa). Di samping perbutannya yang tidak pernah mengganggu dan berbuat jahat kepada orang lain, dengan tidak dimengertinya kata-kata yang diucapkan oleh Amang Gaga membuat ia terpelihara dari perkataan yang menyakiti perasaan orang lain yang mendengarnya.

Karena menurut al-Qusyairi, syarat seorang wali adalah terpelihara sebagaimana syarat seorang nabi yang juga terlindung dari kesalahan. Ia beribadah dengan istiqamah tanpa diselingi perbuatan durhaka. ${ }^{56}$ Namun hal ini cukup membahayakan bila pandangan ini dipercayai secara berlebihan, karena bisa membawa kepada pengkultusan dan pensucian individu secara berlebihan. Padahal sebagaimana manusia pada umumnya, boleh jadi Amang Gaga tidak luput dari dosa dan kekhilafan.

Pandangan masyarakat tentang kewalian Amang Gaga tidak terlepas dari pandangan para tokoh masyarakat, terutama tokoh agama. Ketika tokoh masyarakat ataupun tokoh agama mengatakan dan membenarkan Amang Gaga adalah seorang wali dan memiliki karamah, maka semakin mantaplah keyakinan masyarakat tersebut.

Adapun tokoh agama tersebut di antaranya, pertama, alm Guru H. Abdul Wahab. Beberapa responden mengaku pernah mendengar Guru H. Abdul Wahab mengatakan bahwa Amang Gaga adalah orang yang taat dan konsisten dalam beribadah. Segala keanehan yang terjadi pada dirinya yang dianggap sebagai karamah itu adalah bukti bahwa Awliyâ Allah memiliki keistimewaan di hadapan tuhan. ${ }^{57}$

\footnotetext{
${ }^{55}$ Carl W. Ernst, Ajaran dan Amaliah Tasawnf, terj. Arif Anwar (Jogjakarta: Pustaka Sufi, 2003), 77-78.
}

${ }^{56}$ Abul Qasim Abdul Karim Hawazin Al-Qusyairi An-Naisaburi, Risalah Qushairiyab; Sumber Kajian Ilmu Tasawuf, terj. Umar Faruq (Jakarta: Pustaka Amini, 2007), 383.

57 Guru H. Abdul Wahab adalah orang yang semasa hidupnya dipandang sebagai tuan guru dan memiliki pengajian yang kemudian diteruskan oleh muridnya Lahmudin. Ia juga dipandang masyarakat sebagai Awliyâ Allah, sehingga makamnya dikeramatkan dan terletak di Desa Ujung Lama. Lihat Hamdan, Sulaiman, dan Masteka, Wawancara Pribadi, Ujung Lama, 06 Mei 2016. 
Kedua, alm. KH. Anang Ramli Haq, berdasarkan dari pengakuan salah seorang peserta pengajian di Manjelis Zikir As-syafa'atul Qubra. Dalam pengajian tersebut pernah KH. Anang Ramli membahas tentang kewalian dan karamah salah satunya contoh wali Allah wali yang ada di daerah setempat adalah Amang Gaga. ${ }^{58}$ KH. Anang Ramli Haq tidak pernah memberikan komentar yang menolak pandangan masyarakat terhadap wali dan kekaramahan Amang Gaga. ${ }^{59}$ Selain tokoh tersebut , guru Lahmudin, ${ }^{60}$ guru Bashir desa Ujung. ${ }^{61}$ guru Enor (Noor Iriansyah), ${ }^{62}$ dan guru Sulaiman. ${ }^{63}$ Mereka sepakat bahwa Amang Gaga seorang awliyâ'Allah.

Adapula sebagian masyarakat yang mengklaim Amang Gaga sebagai seorang wali Allah itu mereka yang memiliki sedikit pemahaman tentang masalah kewalian. Keyakinan mereka timbul hanya karena kepercayaan orang-orang di sekelilingnya yang sudah tertanam sejak lama, mereka menerima saja tanpa menggali lebih jauh makna kewalian dan karamah itu sendiri.

Namun bagi masyarakat (responden) yang pernah bertemu dengan Amang Gaga atau dalam hal ini orang yang pernah semasa mereka dengan kokoh meyakininya. Bahkan beberapa di antara mereka (responden dan informan) mengaku ikut serta menyaksikan karamah sebagai bukti dari kewalian Amang Gaga.

Berdasarkan data di lapangan, penulis menemukan masyarakat umumnya menyatakan bahwa adalah wali yang termasuk dalam tingkatan awliyâ` Allah, dan ada pula yang mengatakan Amang Gaga termasuk dalam tingkatan wali gawst atau wali quthub. ${ }^{64}$ Bahkan ada pula yang mengatakan Amang Gaga termasuk dalam golongan wali majd乏û́b. ${ }^{65}$

Wali ghawst atau wali quthub dalam pandangan Imam Ibnu Arabi dan Imam Al-Manawi, yakni menurut mereka wali Aqtab (wali Quthub) atau disebut juga dengan ghawts, ialah wali yang dalam dirinya terdapat segala sesuatu yang bertalian dengan kewalian dan tingkatan. Menurut kaum sufi, wali inilah yang menjadi pemimpin bagi wali lainnya. Jumlahnya hanya ada satu pada setiap masa. Ketika meninggal baru digantikan dengan wali yang lainnya. ${ }^{66}$

Akan tetapi memiliki kesamaan dengan pengertian wali ghawst atau wali quthub dalam pandangan ulama Banjar yang dapat ditelusuri dari beberapa kitab atau risalah terutama kitab al-Risâlat al-Nûrâniyyah dan dapat pula ditelusuri dari rangkaian doa $\underline{h}$ awl yang mencantumkan tingkatan para wali secara berurutan dalam teks doanya tersebut. Walau sejauh penelusuran yang peneliti lakukan tidak ada hal yang membuktikan bahwa Amang Gaga merupakan seorang pemimpin wali-wali yang lainnya.

\footnotetext{
58 Masteka, Wawancara Pribadi, Ujung Lama, 25 April 2016.

59 Ahmad Rodhiani, Wawancara Pribadi, 09 Juni 2016.

${ }^{60} \mathrm{Ia}$ adalah penerus dari pengajian yang dulunya di pegang oleh dari alm Guru H. Abdul Wahab. Lihat Lahmudin, Wawancara Pribadi, Ujung Lama, 07 April 2015.

${ }^{61}$ Guru pengajian malam rabu di jalan Kamajaya. Amang Gaga adalah seorang yang sangat cerdas, taat beribadah, dan termasuk dalam golongan wali Allah. Lihat Bashir, wawancara pribadi, Ujung Lama, 25 April 2016.

62 Amang Gaga adalah wali majdzub. Lihat Noor Iriansyah, Wawancara Pribadi, Ujung Lama, 16 Juni 2015.

${ }^{63}$ Sulaiman, Wawancara Pribadi, Ujung Lama, 06 Mei 2016.

${ }^{64}$ Dari wawancara yang dialukan ada 7 orang responponden yang mengatakan bahwa Amang Gaga adalah wali majdzub.

${ }^{65}$ Saiyah, Wawancara Pribadi, Ujung Lama, 11 Maret 2016.

${ }^{66}$ Fuad Said, Keramat Wali-wali (Jakarta: Pustaka Alhusna,1993), 17.
} 
Menurut ulama Banjar al-Risâlat al-Nûrâniyyah, al-quthub atau al-ghawts adalah pemimpin bagi wali yang lain, yang terhormat dan diagungkan. Dia adalah orang yang pemurah, manusia membutuhkannya ketika mengalami kesulitan, doanya terkabul sehingga orang berdoa melalui perantaraannya. Ia memiliki tasharruf (bertindak sekehendaknya) dan imdâd (memberi bantuan) kepada seluruh awliyâ baik yang masih hidup maupun yang telah wafat. Jumlahnya hanya ada satu pada setiap masa. ${ }^{67}$

Berpatokan dari pendapat ulama Banjar yang telah disebut diatas, maka anggapan masyarakat tentang Amang Gaga termasuk dalam tingkatan wali al-quthub atau al-ghawts ada benarnya karena seringnya manusia membutuhkannya ketika mengalamai kesulitan, dan dijadikan perantara dalam berdoa kepada Allah. Sehingga masyarakat memiliki harapan adanya kemungkinan atau peluang terkabulkannya doa mereka tersebut.

Adapun mereka yang menganggap Amang Gaga termasuk awliyâ`Allah beralasan bahwa Amang Gaga orang yang beriman dan memiliki ketakwaan kepada Allah namun Amang Gaga tidak pernah mengakuinya, bahkan seperti tidak mengetahui tentang kewalian dirinya sendiri. Hal ini berbeda dengan wali syaitan yang mengaku dirinya seorang wali tetapi dalam sikap dan perbuatannya sama sekali tidak mencerminkan adanya ketakwaan kepada Allah, dan cendrung menuruti syaitan. ${ }^{68}$ Sesuai dengan pendapat Ibnu Taimiyah yang mengatakan bahwa kewalian syaitan didapatkan dengan menuruti syaitan, seperti berbuat kefasikan, kekafiran, kesyirikan, penyimpangan dari ajaran-ajaran yang disampaikan Nabi Muhammad saw, dan tidak mengekuti beliau lahir dan batin. ${ }^{69}$

Sedangkan menurut responden yang menganggap Amang Gaga sebagai wali majdðûu, menjelaskan bahwa seorang wali yang majdzûub ialah seorang wali yang langsung diambil atau dilantik tuhan sehingga sangat dekat dengan Allah, dipelihara, dan menduduki derajat kewalian. ${ }^{70}$ Adapun dalam dunia tasawuf wali yang disebut wali majd₹ûb atau jadz̧ab adalah suatu istilah yang digunakan untuk orang yang berada dalam kekuasaan Allah layaknya bayi dalam buayan ibunya. Perbuatannya selalu dalam kekuasaan Allah, ibarat tindakan seorang ibu terhadap anaknya. ${ }^{71}$

Ada ciri umum yang dipakai dalam dunia tasawuf untuk mengetahui siapa yang mendapatkan karamah yang telah diberitahukan Allah. Salah satunya karamah itu akan Allah berikan kepada hambanya yang selalu dekat kepada-Nya, karena ketakwaan dan keikhlasannya dalam beribadah kepada Allah. Sehingga karamah tidak dapat diberikan kepada orang yang lalai atau menyimpang dari syariat Islam. ${ }^{72}$ Apabila diberikan kepada keluar biasaan tersebut diberikan Allah kepada orang-orang yang fasik, atau musuh-musuh Allah, yang

${ }^{67}$ Rahmadi dkk., Manakib Karya Ulama Banjar (Penelusuran Pemikiran Sosio-Mistis), 182.

${ }^{68}$ Lahmudin, Wawancara Pribadi, Ujung Lama, 07 April 2015.

${ }^{69}$ Ibnu Taimiyyah, Wali Allah atau Wali Syaitan (Ciri, Syarat, dan Tanda-tanda yang Membedakan Wali Allah dan Wali Syaitan), terj.Umar Mujtahid (Jakarta: Pustaka Imam Syafi'i), 12.

${ }^{70}$ Lahmudin, Wawancara Pribadi, Ujung Lama, 07 April 2015.

${ }^{71}$ Tim Penyusun Santri KH. Munawir Kertosono Ngamjuk dan Santri KH. Sholeh Bahruddin Sengonagung Purwosari Pasuruan, Sabilus Sâlikin: Jalan Para Salik: Ensiklopedi Thariqah dan Tashawnuf(Pasuruan: Ponpes Ngalah, 2014$), 170$.

${ }^{72}$ Harun Nasution, Falsafat dan Mistisisme dalam Islam (Jakarta: Bulan Bintang, 1987), 67. 
membawa malapetaka dan bisa membuat mereka binasa, mereka akan membuat mereka sombong dan merasa dirinya mulia dan utama, maka ini disebut dengan istidrajj. ${ }^{73}$

Semua yang terjadi membuat Amang Gaga dihormati oleh masyarakat, tetapi sedikitpun tidak membuatnya sombong. Bahkan salah seorang responden menceritakan bahwa Amang Gaga seakan tidak menyadari keluarbiasaan yang ada pada dirinya, apalagi menyombongannya. ${ }^{74}$ Sehingga keluarbiasaan yang terjadi pada diri Amang Gaga bukanlah istidraj (keluarbiasaan yang diberikan Allah kepada orang-orang yang fasik, atau musuh-musuh-Nya yang merupakan ujian yang membawa malapetaka dan bisa membuat mereka binasa, sebab istidrâj di dalam diri mereka akan membuat mereka sombong dan merasa dirinya mulia dan utama). ${ }^{75}$

Selain itu, keluarbiasaan atau keistimewaan yang ada dalam diri Amang Gaga bukan merupakan suatu mukjizat ataupun irhas. Mukjizat merupakan suatu keluarbiasaan yang terjadi pada seorang Nabi dan rasul, sedangkan Amang Gaga bukanlah seorang Nabi dan bukan pula seorang Rasul. Keluarbiasaan yang Amang Gaga miliki juga tidak bisa dikatakan sebagai irbas ${ }^{76}$ karena keluarbiasaan Amang Gaga tersebut bukan permulaan dari suatu kenabian dan tidak pula diiringi pengakuan diri sebagai seorang nabi.

Kejadian luar biasa atau istimewa pada Amang Gaga bukan pula termasuk maunah, karena maunah adalah pertolongan yang Allah berikan kepada orang mukmin yang merupakan peristiwa luar biasa untuk mengatasi kesulitan yang menurut akal sehat melebihi dari kemampuannya. Maunah terjadi pada orang biasa berkat perolongan Allah. Contohnya, orang yang terjebak kobaran api yang sangat besar, namun ia selamat. ${ }^{77}$

Jika berpatokan pada data yang penulis dapatkan dilapangan maka akan didapati bahwa Amang Gaga tergolong orang yang takwa ${ }^{78}$ kepada Allah dan dianggap memiliki kedekatan kepada-Nya, maka apa saja yang timbul dari dalam diri Amang Gaga yakni sesuatu yang diluar dari kebiasaan atau bertentangan dari hukum alam yang dianggap sebagai karamah oleh masyarakat bisa jadi merupakan suatu yang benar, selama tidak bertentangan dengan syariat Islam.

Jika dilihat dari Al-Hakim al-Tirmidzi dan al-Husaini yang membagi karamah menjadi dua yaitu karamah al-hisiyyah atau karamah yang bersifat fisik-indrawi dan karamah al-ma'nawiyyah atau karamah yang bersifat ma'nawi. ${ }^{79}$ Masyarakat hanya cendrung terpesona pada karamah yang bersifat indrawi. Maka karamah

${ }^{73}$ Tim Penulis UIN Syarif Hadiyatullah, Ensiklopedi Tasawnf Jilid II (Bandung: Angkasa, 2008), 665.

${ }^{74}$ Saiyah, Wawancara Pribadi, Ujung Lama, 11 Maret 2016.

${ }^{75}$ Tim Penulis UIN Syarif Hadiyatullah, Ensiklopedi Tasawnf Jilid II, 665.

${ }^{76}$ Irhas adalah kejadian yang luar biasa atau keistimewaan yang diberikan oleh Allah SWT kepada diri seorang calon Nabi atau Rasul seperti melindunginya awan atas Nabi Muhammad sebelum beliau diutus Allah, dan Nabi Isya yang ketika masih bayi dapat berbicara kepada orang-orang yang melecehkan ibunya. Lihat http://wmw.masuk-islam.com/inilah kejadian-kejadian-luar-biasadalam-islam-mukjizat-karomah-maunah-dan-irhas.html, diakses pada 17 Februari 2016.

${ }^{77}$ http:/ / wnm.masuk-islam.com/inilab kejadian-kejadian-luar-biasa-dalam-islam-mukjizat-karomah-maunah-dan-irhas.html, diakses pada 17 Februari 2016.

${ }^{78}$ Takwa mengacu pada ketaatan dan kecintaan kepda Allah. Mereka yang takwa memiliki kesadaran bahwa dia selalu berdiri di hadapan Tuhan dan bahwa Tuhan selalu mengetahui segala sesuatu yang ada dalam dirinya, bahkan pikiran-pikiran yang paling rahasia yang jauh di dalam lubuk hatinya. Lihat Seyyed Hossein Nasr, Ensiklopedi Tematis Spiritualitas Islam, terj. Rahmani Astuti (Bandung: Mizan, 2002), 209. 
dalam pandangan masyarakat itu hanyalah karamah indrawi atau karamah al-bisiyyah. Sedangkan istiqamah yang sebenarnya menurut Al-Hakim al-Tirmidzi dan al-Husaini merupakan karamah al-ma'nawiyyab, ${ }^{80}$ dalam pandangan masyarakat bukanlah sebuah karamah tetapi hanya sebagai jalan Amang Gaga mendapatkan karamahnya.

Padahal menurut penilian para ahli hakikat (al-muhaqqiqûn) yang tertera dalam Ensiklopedia Tasawnf jilid II, karamah al-ma'nawiyyah merupakan karamah yang lebih unggul, karamah yang paling hakiki. ${ }^{81}$ Jika seseorang memiliki sikap istiqamah dalam beragama dan mendapat keyakinan yang sempurna, kemudian pada dirinya terdapat khawâriq al-âdah maka akan ada dua kemungkinan, maka pemilik karamah itu harus diberi penghormatan, karena karamah yang demikian merupakan bukti dari kesempurnaan seorang wali Allah. Namun jika tidak disertai dengan sikap istiqamah, maka apapun khawâriq al-âdah yang dilakukannya itu sama sekali tidak ada nilainya.

\section{Penutup}

Berdasarkan uraian yang telah dipaparkan, maka dapatlah diambil suatu kesimpulan sebagai berikut:

1. Masyarakat memandang bahwa Amang Gaga seorang wali karena tiga hal, yaitu:

a. Ketaatannya yang nyata, seperti melakukan apa yang diperintahkan dan menjauhi larangannya, serta mengamalkan sunnah nabi.

b. Amang Gaga orang yang ma'shum (terjaga dari segala perbuatan dosa, tidak suka mengganggu dan berbuat jahat kepada orang lain).

c. Keistiqamahannya dalam ibadah seperti selalu menunaikan kewajiban sebagai hamba Allah, dan ditambah dengan amalan sunnah seperti sholat malam, dzikir, mengaji, menjaga silaturrahmi, berpakaian sopan menutup aurat, dan makan dengan adab seperti nabi.

d. Karamahnya yang luar biasa dan menyalahi dari kebiasaan.

2. Kewalian dan karamah Amang Gaga dalam tinjauan tasawuf dapat diterima karena ada syarat-syarat kewalian yang tampak dari Amang Gaga seperti terlihatnya keimanan dan ketakwaannya dalam kehidupan sehari-hari. Dia termasuk tingkatan wali al-quthub atau al-ghawts karena manusia membutuhkannya ketika mengalami kesulitan, doanya terkabul sehingga orang berdoa melalui perantaraannya, meskipun tidak ada hal yang membuktikan bahwa Amang Gaga merupakan pemimpin dari para wali. Amang Gaga termasuk awliyâ Allah. Ia telah ditarik oleh Allah secara metafisis (majd乏û́b) kedalam derajat walâyah sebelum mujahadah, semata-mata didasarkan kepada keberlakuan berkah atau minnah.

3. Sedangkan hal-hal yang selama ini dianggap masyarakat sebagai karamah Amang hanyalah karamah albisiyyah atau karamah yang bersifat fisik-indrawi, sesuatu yang tidak lazim atau bertentangan dengan kebiasaan dan hukum alam secara fisik atau indrawi. Sedangkan karamah al-ma'nawiyyah atau karamah yang

${ }^{80}$ Karamah yang kedua ini merupakan sikap istiqamah dalam menjalin hubungan dengan Allah lahir-batin yang menyebabkan hijab tersingkap (kasyf) dari qalbunya hingga ia mengenal Allah kekasihnya serta merasakan ketentraman batin dengan Allah. Lihat Tim Penulis UIN Syarif Hadiyatullah, Ensiklopedi Tasawnf Jilid II, 666-667.

${ }^{81}$ Tim Penulis UIN Syarif Hadiyatullah, Ensiklopedi Tasawnf Jilid II, 666. 
bersifat ma'nawi sama sekali tidak disadari, padahal itu adalah karamah yang paling penting. Karamah ma'nawiyyah ini merupakan sikap istiqamah dalam menjalin hubungan dengan Allah lahir-batin yang menyebabkan hijab tersingkap (kasyf) dari qalbunya hingga ia mengenal Allah kekasihnya serta merasakan ketentraman batin dengan Allah.

\section{DAFTAR PUSTAKA}

Amstrong, Amatullah. Khazanah Istilah Sufi: Kunci Memasuki Dunia Tasawnf. terj. Nasrullah Dan Ahmad Baiquni. Bandung: Mizan, 2000.

Anita. "Konsep Wali Dan Karamah Dalam Ajaran Tasawuf Al-Qusyairi” (Telaah Kitab Ar-Risalah Qusyairi)." Tesis. Banjarmasin: Pasca Sarjana IAIN Antasari, 2007.

Arikunto, Suharsimi. Manajemen Penelitian. Jakarta: Renika Cipta, 1995.

Prosedur Penelitian Suatu Pendekatan Praktek. Jakarta: Renika Cipta, 1998.

Badan Pemberdayaan Masyarakat dan Pemerintahan Desa Kabupaten Tanah Laut Provinsi Kalimantan Selatan, Profil Desa dan Kelurahan yang Diperoleh Di Kantor Desa Ujung Baru Kecamatan Bati - Bati Kab. Tanah Laut Tabun 2015.

Bakar, Abu Jabir El-Jazair. Pola Hidup Muslim: Aqidah. terj. Rachmat Pjatnika Dan Ahmad Sumpeno. Bandung: Remaja Rosdakarya, 1990.

Bangun, Ahmad Nasution, dan Rayani Hanum Siregar. Akblak Tasawn: Mengenal, Pemahaman, Dan Pengaplikasiannya Disertai Biografi Dan Tokoh-Tokoh Sufi. Jakarta: Rajawali Pers, 2013.

Basrowi, dan Suwardi. Memahami Penelitian Kualitatif. Jakarta: Renika Cipta, 2008.

Chodkiewicz, Michel. Konsep Ibn 'Arabi tentang Kenabian dan Aulia, terj. Dwi Surya Atmaja. Jakarta: Raja GrfindoPersada, 2002.

Dahri, Harapandi. Wali dan Keramat dalam Islam. Jakarta: Balai Penerbitan dan Pengembangan Agama, 2007.

Daud, Alfani. Islam dan Masyarakat Banjar: Diskripsi dan Analisa Kebudayaan Banjar. Jakarta: Raja Grafindo Persada, 1997.

Diana. "Persepsi Masyarakat Tentang Karamah Wali Utuh Amut Di Desa Sungai Durait Tengah Kec. Babirik Kab. Hsu," Skripsi. Banjarmasin: Fakultas Ushuluddin Dan Humaniora IAIN Antasari, 2014.

Djebar, Abdul Hapip. Kamus Bahasa Banjar - Indonesia. Kalimantan- Banjarmasin: Grafika Wangi, 1986.

Fachruzie, Irham. Betulkanlah Taubid Anda: Menguak Rahasia Agama dan Kebertubanan. Surabaya: Al-Ihsan, 2000.

Harahap, Syahrin, dan Hasan Bakti Nasution, Ensiklopedia Akidab Islam. Jakarta: Kencana 2009.

Hossein, Seyyed Nasr. Ensiklopedi Tematis Spiritualitas Islam. terj. Rahmani Astuti. Bandung: Mizan, 2002.

Al-Husayn, Abu Muslim Ibn Al-Hajjaj Ibn Muslim Al-Qusyairi Al-Naisabury. Al-Jami' Al-Shabih (Td), Juz 6.

Jumantoro, Totok dan Samsul Munir Amin. Kamus Ilmu Tasawuf. T.t: Amjah, 2005.

Labib. Perbedaan Wali Allah Dengan Wali Syaitan. Surabaya: Bintang Usaha Jaya, 2004.

Lawrence, Bruce B., Carl W. Ernst, dan Beend Radtke. Cinta, Guru, dan Kewalian dalam Sufisme Awal. terj. Ribut Wahyudi. Yogyakarta: Pustaka Sufi, 2003.

Moleong, Lexy J., Metodologi Penelitian Kualitatif. Bandung: Remaja Rosdakarya, 1992.

Mursito, Lilik. Wali Allah Menurut Al-Hakim Al-Tirmidzi Dan Ibn Taimiyah. Jurnal Kalimah, Vol. 13, No.1, Maret 2015. 
Mustafa. Filsafat Islam. Bandung: Pustaka Setia. 1997.

Al-Nabhani. Jämi’ Karāmāt al-Awliyā’ . Jilid I. Lebanon: Dār al-Fikri, 1993

Nasution, Harun. Falsafat Dan Mistisisme Dalam Islam. Jakarta: Bulan Bintang, 1987.

Ni'am, Syamsun. Tarekat, Konsep Kewalian, Dan Tradisi Haul: Kritik Kh. Hasyim Asy'ari. Jurnal Istiqro', Vol. 06, No.01, 2015.

Nisa, Mufidatun. "Manaqib Syiekh Abdul Hamid Abulung (Telaah Sufistik Wali Dan Karamah)." Tesis. Banjarmasin: Pasca Sarjana IAIN Antasari, 2009.

Prayogo, Imam Tobrani, Metodologi Penelitian Sosial-Agama. Bandung: Remaja Rosdakarya, 2001.

Al-Qahthani, Said bin Musfir. Buku Putih: Syaikh Abdul Qadir Al-Jailani. Terj. Munirul Abidin, Darul Fatah.

Al-Qardhawi, Yusuf. Alam Ghaib: Sikap Islam Terhadap Ilham, Kasyaf, Mimpi, Jimat, Ramalan, Dan Mantra. Terj. M. Wahid Aziz. Jakarta: Senayan Abadi Publishing, 2003.

Qasim, Abul Abdul Karim Hawazin Al-Qusyairi An-Naisaburi. Risalah Qushairiyah; Sumber Kajian Ilmu Tasawuf. terj. Umar Faruq. Jakarta: Pustaka Amini, 2007.

Rahmadi, dkk. Manakib Karya Ulama Banjar (Penelusuran Pemikiran Sosio-Mistis). Banjarmasin: Antasari Press, 2007.

Rahmadi, Pengantar Metodologi Penelitian. Banjarmasin: Antasari Press, 2011.

Ryandi. Konsep Kewalian Menurut Hakim Tirmidzi. Jurnal Kamilab Vol. 12, No. 2, September 2014.

Sabiq, Sayyid. Aqidah Islamiyah. Terj. Ali Mahmudi. Jakarta: Robbani Press.

Said, Fuad. Keramat Wali-wali. Jakarta: Pustaka Alhusna, 1993.

Saifulloh, Moh. Al-Aziz Senali. Tashawnuf Dan Jalan Hidup Para Wali. Gersik: Putra Pelajar, 2000.

Subhani, Ja'far. Tawassul, Tabarruk, Ziarah Kubur, Karamah Wali Termasuk Ajaran Islam : Kritik Atas Faham Wababi. Bandung: Pustaka Hidayah, 1995.

Sugiyono. Memahami Penelitian Kualitatif. Bandung: Alfabeta, 2013.

Sukma, Muhammad Santoso. "Fenomena Wali Galung Bati-Bati," Skripsi. Banjarmasin: Fakultas Ushuluddin Dan Humaniora IAIN Antasari, 2012.

Surat Keputusan Kepala Desa, Rencana Kerja Pembangunan Desa Jangka Panjang Tahun 2011-2015 (Rpjmdesa).

Taimiyah, Ibnu. Syarah Al-Aqidah Al-Wasithbiyah. Terj. Yazid Bin Abdul. Jakarta: Darul Haq, 2001.

-------. Wali Allab Menurut Al-Qur'an. Terj. Ja'fat Sujarwo. Surabaya: Al-Ikhlas.

Wali Allah Atau Wali Syaitan (Ciri, Syarat, Dan Tanda-Tanda Yang Membedakan Wali Allab Dan Wali Syaitan). Terj.Umar Mujtahid. Jakarta: Pustaka Imam Syafi'i.

Tim Penulis UIN Syarif Hadiyatullah, Ensiklopedi Tasawuf Jilid II. Bandung: Angkasa, 2008.

Tim Penyusun Fakultas Ushuluddin. Pedoman Menulis Karya Ilmiah. Banjarmasin: Fakultas Ushuluddin dan Humaniora IAIN Antasari, 2015.

Tim Penyusun Santri KH. Munawir Kertosono Nganjuk Dan Santri KH. Sholeh Bahruddin Sengonagung Purwosari Pasuruan. Sabilus Sälikin Jalan Para Salik: Ensiklopedi Thariqah Dan Tashawnuf. Pasuruan: Ponpes Ngalah, 2014.

Tim Penyusun Kamus Pusat Pembimbingan Dan Pengembangan Bahasa, Kamus Besar Bahasa Indonesia. Jakarta: Gramedia Pustaka Utama, 2008.

Umari, Barmawi. Sistematika Tasawuf. Solo: Ramadhani, 1994. 
Usman, Asep Ismail. Apakah Wali Itu Ada. Jakarta: Raja Grafindo Persada, 2015.

W. Carl Ernst. Ajaran Dan Amaliah Tasawnf. terj. Arif Anwar. Jogjakarta: Pustaka Sufi, 2003.

Yunus, Mahmud. Kamus Arab Indonesia. Jakarta: Mahmud Yunus Wa Dzurriyyah, 2010.

Zahri, Mustafa. Kunci Memahami Ilmu Tasawuf. Surabaya: Bima Ilmu, 2007.

\section{SUMBER INTERNET}

Http://Www. Pengertian dan Contoh Mukjizat, Irhas, Maunah dan Istidraj_ Anita's World.htm. Diakses pada 17 Februari 2016.

Http://Www.Masuk-Islam.Com/InilabKejadian-Kejadian-Luar-Biasa-dalam-Islam Mukjizat-Karomah-Maunah-DanIrhas.Html. Diakses pada 17 Februari 2016.

Muhammad Trihan. "Hierarki Kewalian", Dalam Sufi Zona, http://Www.Sufinews.Com/Index.Php/Koleksi/Peofile-Sufi/Dunia-Wali/Item/1406-HierarkiKewalian, Diakses pada 25 Januari 2016. 